\title{
Residues of oxolinic acid in wild fauna following medication in fish farms
}

\author{
O. B. Samuelsen ${ }^{1}$, B. T. Lunestad ${ }^{2}$, B. Husevåg ${ }^{2}$, T. Hølleland ${ }^{3}$, A. Ervik ${ }^{4}$ \\ ' Department of Pharmacology and Toxicology, University of Bergen, Armauer Hansens Hus, N-5021 Bergen, Norway \\ ${ }^{2}$ Department of Microbiology and Plant Physiology, University of Bergen, Jahnebakken 5, N-5007 Bergen, Norway \\ ${ }^{3}$ Directorate of Fisheries, Fisheries Advisory Service, Hordaland region, Slottsgaten 3, N-5000 Bergen, Norway \\ ${ }^{4}$ Institute of Marine Research, Department of Aquaculture. Strandgaten 229, N-5024 Bergen, Norway
}

\begin{abstract}
Dispersion of oxolinic acid and occurrence of Aeromonas salmonicida in wild fauna were studied in animals captured in the vicinity of 2 aquaculture facilities during and after medication with this drug. Consumption of antibacterial agents in aquaculture has reached a considerable level. The major part of the drugs used reach the environment, either directly due to excessive feeding and reduced appetite of the cultured fish, or indirectly after having passed through the fish. Some of the drugs entering the environment are taken up by exploitable wild fish, shellfish and crustaceans, resulting in concentrations far above those accepted in food for human consumption in Norway. The concentration of oxolinic acid in muscle and liver was highest in pelagic fish like coalfish and mackerel. The mean concentration in muscle of all positive samples at the day of medication termination were $4.38 \mu \mathrm{g} \mathrm{g}^{-1}$ and $0.42 \mu \mathrm{g} \mathrm{g}^{-1}$ at 2 different farms. Maximum concentration of oxolinic acid in muscle samples was $12.51 \mathrm{\mu g} \mathrm{g}^{-1}$ We found a simultaneous occurrence of oxolinic acid and the fish pathogenic bacterium $A$. salmonicida in the gut of both cultured and wild fish. This may lead to development and dispersion of resistant bacteria. Blue mussels Mytilus edulis harvested at one of the farms contained an elevated level of bacteria resistant to oxolinic acid.
\end{abstract}

\section{INTRODUCTION}

Bacterial diseases are considered a major problem in fish farming. Even though much work has been done to prevent outbreaks of such diseases, considerable amounts of antibacterial substances are still prescribed. In Norway, oxytetracycline (OTC), furazolidone (FZ) and trimethoprim/sulfa drugs were for many years the substances of first choice. However, since 1987 quinolones, especially oxolinic acid (OA), have found broader use (Fig. 1). In 1990 OA represented $74 \%$ by weight of all antimicrobial drugs prescribed in the treatment of fish in Norwegian aquaculture (statistics provided by Norwegian Medicinal Depot, Oslo).

Oxolinic acid (5-ethyl-5,8-dihydro-8-oxo-1,3-dioxolo $\{4,5-g\}$ quinoline-7-carboxylic acid) is a weak acid with $\mathrm{pK}_{\mathrm{a}}$ at 6.9 . It is practically insoluble in acidic solutions but very soluble in alkaline media. In humans, $\mathrm{OA}$ is converted into at least 8 metabolites which are excreted principally as glucuronides (DiCarlo et al. 1968). Crew et al. (1971) examined the metabolism of OA in rats, rabbits and dogs; they reported that, quan- titatively, none of these animals metabolised OA as humans. Qualitatively, however, rats, rabbits and dogs transformed oxolinic acid in a manner similar to that in humans. The molecular structure of oxolinic acid is shown in Fig. 2.

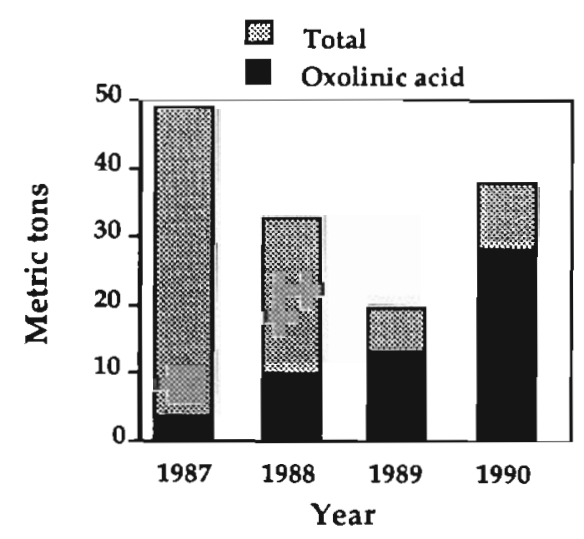

Fig. 1. Total amount of antibacterial agents and amount of oxolinic acid used in Norwegian aquaculture in the years 1987 to 1990 


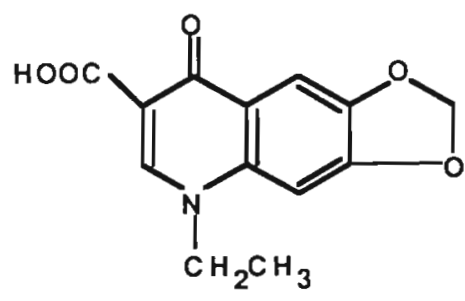

Fig. 2. Molecular structure of oxolinic acid

Bacterial infections in fish are commonly treated using food pellets containing the desired antibacterial substance. However, diseased fish often show reduced appetite and an over-feeding may occur, leading to medicated food pellets entering the surroundings During feeding, fragments containing the antibacterial agent may fall off, or the drug may be released from the pellet in a dissolved form (Higuera et al. 1990). Further, preliminary experiments using OA as the antibacterial agent have shown that some of the drug eaten by the farmed fish is excreted in an unchanged active form via the urine or faeces (Samuelsen unpubl.). Hence, considerable amounts of the drug will enter the enviconment either directly due to overfeeding or indirectly after having passed through the animal under treatment. Therefore, during chemotherapy of farmed fish, the wild fauna may be exposed to varying amounts of drugs, sometimes on severa] occasions during a year

Particle-bound medicine can be taken up by filterfeeders such as appendicularians or mussels and dissolved drugs can be absorbed by organisms directly from the water (Nusbaum \& Shotts 1981). Using a microbiological method, Møster (1986) found residues of OTC in blue mussels Mytilus edulis harvested $80 \mathrm{~m}$ from the application area. Medicated faeces and food pellets also reach the bottom deposits under the farms in considerable amounts (Jacobsen \& Berglind 1988, Björklund et al. 1990, Samuelsen et al. in press). The occurrence of OTC in fish caught near a rearing facility for rainbow trout Oncorhynchus mykiss on the southwest coast of Finland was investigated by Björklund et al. (1990).

They found OTC levels ranging from 0.2 to $1.3 \mu \mathrm{g} \mathrm{g}^{-1}$ in 8 muscle samples of bleak Alburnus alburnus L. collected on the last day of medication. The medication regime applied was $100 \mathrm{mg}$ OTC ( $\mathrm{kg}$ fish) $)^{-1} \mathrm{~d}^{-1}$ for $10 \mathrm{~d}$. They also found that roach Rutilus rutilus L., caught near a salmon farm 1 d after terminated medication, had OTC levels in muscle in concentrations close to the detection limit of the HPLC method $\left(0.05 \mu \mathrm{g} \mathrm{g}^{-1}\right)$. The farms described by Björklund were located in an area with brackish water of salinity ca $5 \%$. Bleak and roach are typical species in brackish or freshwater fauna. In coastal areas of countries including Norway and Scot- land, coalfish Pollachius virens, cod Gadus morhua, mackerel Scomber scombrus, ballan wrasse Labrus bergylta and haddock Melanogrammus aeglefinus are the most common species found in the vicinity of marine aquaculture sites (Carss 1990). No findings concerning possible $O A$ residues in the wild fauna near Norwegian salmon farms have yet been published. The present study was undertaken to obtain information on the occurrence and concentrations of OA in the wild fauna in the vicinity of 2 salmon farms located on the west coast of Norway. The occurrence of the bacterium Aeromonas salmonicida in the gut content of both farmed and wild fish and the number of bacteria resistant to $O A$ in $M$. edulis were also studied. A. salmonicida is the causative agent of furunculosis, at present the most severe disease of bacterial origin in Norwegian aquaculture.

\section{MATERIALS AND METHODS}

Sampling sites. Samples of cultivated fish, wild fish, crabs and blue mussels were collected at 2 marine aquaculture facilities on the west coast of Norway during October and November 1990. On Farm 1, $134000 \mathrm{~kg}$ of salmon Salmo salar L. suffering from furunculosis were treated for $10 \mathrm{~d}$ using a total of $34 \mathrm{~kg}$ OA distributed in $11200 \mathrm{~kg}$ moist pellets. This farm represents a typical Norwegian fish farm in size and stock. Average seawater temperature was $9^{\circ} \mathrm{C}$ during the sampling period and the water depth under the cages varied between 40 and $70 \mathrm{~m}$. The farm was located in a narrow strait with tidal currents in alternating directions.

On Farm 2, $18000 \mathrm{~kg}$ salmon suffering from vibriosis (Vibrio anguillarum) were treated for $8 \mathrm{~d}$ using a total of $9.84 \mathrm{~kg}$ OA distributed in $1.928 \mathrm{~kg}$ dry pellets. Average seawater temperature was $11{ }^{\circ} \mathrm{C}$ during sampling and the water depth under the cages varied between 30 and $60 \mathrm{~m}$.

Sampling. Samples were collected on the last day of medication (Day 0) at both farms and at Days 4, 7 and 13 (Farm 1) and Days 7 and 13 (Farm 2) following medication. Wild fish weighing between 0.6 and $5 \mathrm{~kg}$ were caught using fishing lines or with nets placed within $400 \mathrm{~m}$ of the farms. Crabs were caught both in nets and traps, and blue mussels were collected with a landing net or by divers. Samples of muscle, liver and blood were taken from the fish immediately after the catch was landed. Haemolymph and muscle samples were collected from the crabs. Haemolymph and blood samples were taken using a heparinized 1 ml syringe, centrifuged at $15000 \times \mathrm{g}$ on the farm using a Biofuge A centrifuge (Heraeus Sepatech, Osterode am Harz, Germany) keeping only the plasma fraction. A 
total of 46 samples of gut contents were taken from wild and cultivated fish at Farm 1 during the sampling period. All samples were kept on ice in the dark. Samples of the gut contents and blue mussels used in the microbiological assays were prepared and analysed on the day of sampling, at once on return to the laboratory. This was also the case with the plasma samples analysed for OA residues using high-performance liquid chromatography (HPLC). For determination of OA residues, the blue mussels, muscle samples from crabs and fish, and liver samples from fish were kept at $-20^{\circ} \mathrm{C}$ until analysed.

Analysis. Plasma samples $(100 \mu l)$ were analysed for $O A$ residues following the method described by Samuelsen (1990). Standard curves for OA in the range 0.01 to 1 and 1.0 to $2.5 \mu \mathrm{g} \mathrm{ml}^{-1}$ were prepared using drug-free plasma of salmon, coalfish and crab. Flumequine was used as internal standard in a concentration of 1.0 and $2.5 \mu \mathrm{g} \mathrm{ml}^{-1}$ plasma respectively.

The tissue samples were prepared for HPLC following the procedure of Samuelsen (1989) with minor modifications. Muscle (crabs and fish), liver (fish) and soft tissue homogenate (blue mussels) ( $1 \mathrm{~g}$ ) from each organism were weighed, homogenized with two $20 \mathrm{ml}$ portions of Mcllvaine buffer ( $\mathrm{pH} 3.6$ )-methanol (55-45) at high speed for $1 \mathrm{~min}$ and centrifuged for $10 \mathrm{~min}$ at $8000 \times g$ in a Sorvall RC-5B refrigerated superspeed centrifuge (Du Pont Instruments, Newtown, CT, USA). Prior to the first homogenization $0.1,1.0$ or $5.0 \mu \mathrm{g}$ flumequine dissolved in $0.1 \mathrm{M} \mathrm{NaOH}$ was added as an internal standard. The amount of internal standard added to the muscle and liver samples were based upon the concentration of OA found in the corresponding plasma samples.

The combined supernatants were filtered (589 Black ribbon, Schleicher \& Schuell, Dassel, Germany) and evaporated under reduced pressure at a temperature of $40^{\circ} \mathrm{C}$ until $15 \mathrm{ml}$ of the solution remained in the flask. Using $5 \mathrm{ml}$ Mcllvaine buffer ( $\mathrm{pH}$ 3.6) for washing, the flask content was transferred to a separating funnel already containing $25 \mathrm{ml}$ of dichloromethane. After gently shaking the separating funnel for ca $1 \mathrm{~min}$, the 2 layers were allowed to separate and the dichloromethane fraction was transferred to a further separating funnel and rinsed with $10 \mathrm{ml}$ of Mcllvaine buffer ( $\mathrm{pH}$ 3.6). The dichloromethane phase containing the drugs was transferred to a small beaker and evaporated to dryness in a water-bath $\left(40^{\circ} \mathrm{C}\right)$ under a stream of nitrogen. The residue was dissolved in 0.25 or $0.5 \mathrm{ml}$ of $0.1 \mathrm{M} \mathrm{NaOH}$ and centrifuged for $5 \mathrm{~min}$ at $15000 \times g$ (Biofuge A centrifuge). This solution (25 $\mu \mathrm{l})$ was used for HPLC.

Standard curves for OA in the range of 0.01 to 0.1 , 0.1 to 1.0 and 1.0 to $10 \mu \mathrm{g} \mathrm{g}^{-1}$ were prepared using drug-free samples of muscle (coalfish, crab and salmon), liver (coalfish, salmon) and homogenised soft tissue (blue mussel). Flumequine was used as internal standard in concentrations of $0.1,1.0$ and $5.0 \mu \mathrm{g} \mathrm{g}^{-1}$ tissue respectively. Standard curves were drawn by plotting the known drug concentration against the ratio of drug to internal standard peak height. These curves were also used to calculate the detection limits. The extraction recoveries of OA and flumequine in plasma and tissues were determined by comparing peak heights from the analysis of samples spiked with $1.0 \mu \mathrm{g} \mathrm{g}^{-1} \mathrm{OA}$ and flumequine with peak heights resulting from direct injection of a standard. The chromatographic assay and HPLC equipment described by Samuelsen (1990) was used to analyse both the tissues and plasma samples.

Linear graphs ( $\mathrm{r}=0.97$ to 0.99 ) were obtained for $\mathrm{OA}$ in plasma $\left(0.01\right.$ to $\left.2.5 \mu \mathrm{g} \mathrm{ml} \mathrm{ml}^{-1}\right)$, homogenised soft tissue, muscle and liver (0.01 to $\left.10 \mu \mathrm{g} \mathrm{g}^{-1}\right)$ samples. Detection limits were calculated to be 0.003 to 0.010 $\mu \mathrm{g} \mathrm{g}^{-1}$ with a signal to noise ratio of 3 , and recoveries were between 85.4 and $93.5 \%$ when blank samples $(1 \mathrm{~g}$ tissue, $100 \mu \mathrm{l}$ plasma) were spiked with $1.0 \mu \mathrm{g}$ OA. Lowest recoveries and highest detection limits were obtained for the liver samples. The standard curves for coalfish were used to calculate the OA residues in all species except salmon, crab and blue mussel.

The occurrence of $\mathrm{OA}$ in the gut contents of fish and the soft tissue of blue mussels was examined using a standard microbiological method applying an OAsensitive organism (Escherichia coli $\mathrm{B}_{6}$ ). Aliquots of $0.05 \mathrm{ml}$ of the sample material was applied on a thin lawn of bacteria on Petri dishes using a sterile plastic syringe. The media used was Luriua Bertani Agar, a standard medium for cultivation of $E$. coli (Difco bacto agar $15 \mathrm{~g}$, Difco bacto tryptone $10 \mathrm{~g}$. Difco yeast extract $5 \mathrm{~g}$, glucose $1 \mathrm{~g}, \mathrm{NaCl} 10 \mathrm{~g}$, distilled water to $1 \mathrm{l}$. $\mathrm{pH}$ adjusted to 7.4 ). Results were read after incubation at $37^{\circ} \mathrm{C}$ for $12 \mathrm{~h}$. Inhibition zones in bacterial growth indicated the presence of antibacterial substances in the sample material. When applying this method, identification of the agent in question cannot be done. However, it is not very likely that other substances either eaten or produced by the fish or produced by bacteria in the gut would give inhibition zones of the magnitude observed here. In this study we therefore consider growth inhibition of $E$. coli as a positive result for the occurrence of $O A$ in the gut.

To quantify the number of $O A$ resistant bacteria associated with the soft parts of the blue mussels a homogenate was plated on agar media containing $10 \mu \mathrm{g} \mathrm{ml}^{-1} \mathrm{OA}$. The number of colony forming bacteria on the media containing $O A$ was compared to the number of bacteria growing on media without any antibacterial agent, indicating the percentage of bacteria resistant to $\mathrm{OA}$ in blue mussels. The media 
Table 1 Residues of oxolinic acid in plasma, muscle and liver, total count of bacteria and the occurrence of Aeromonas salmonicida in faeces from wild fish and farmed salmon at Farm 1 Day: days following medication; Farm: samples taken from salmon inside the cages; 0,50 and $100 \mathrm{~m}$ : distance from the farm; $\mathrm{n}$ : total number of samples examined. Coalfish = Pollachius virens, salmon = Salmo salar. Activity: number of samples containing faecal material with antibacterial activity; A. salm.: number of samples containing $A$. salmonicida in faeces; total count: total number of bacteria per ml faeces

\begin{tabular}{|c|c|c|c|c|c|c|c|c|c|}
\hline \multirow[t]{2}{*}{ Day } & \multirow[t]{2}{*}{ Location } & \multirow[t]{2}{*}{$\mathrm{n}$} & \multirow[t]{2}{*}{ Species } & \multicolumn{3}{|c|}{ Mean concentrations in $\mu \mathrm{g} \mathrm{g}^{-1}$} & \multicolumn{3}{|c|}{ Faeces } \\
\hline & & & & Muscle & Liver & Plasma & Activity & A. salm. & Total count \\
\hline 0 & Farm & 4 & Salmon & 0.7 & 0.4 & 0.08 & 1 & 4 & $3.0 \times 10^{9}$ \\
\hline 0 & $0 \mathrm{~m}$ & 8 & Coalfish & 5.99 & 7.66 & 1.50 & 8 & 0 & $7.4 \times 10^{9}$ \\
\hline 4 & Farm & 5 & Salmon & 0.49 & 0.33 & 0.16 & 1 & 0 & na \\
\hline 4 & $0 \mathrm{~m}$ & 7 & Coalfish & 3.92 & 2.47 & 0.69 & 7 & 0 & na \\
\hline 7 & Farm & 6 & Salmon & 0.06 & 0.04 & 0.06 & 0 & 2 & $2.7 \times 10^{8}$ \\
\hline 7 & $0 \mathrm{~m}$ & 1 & Salmon & 0.00 & 0.00 & 0.00 & 0 & 1 & $2.6 \times 10^{9}$ \\
\hline 7 & $50 \mathrm{~m}$ & 1 & Salmon & 0.23 & 0.47 & 0.18 & 1 & 1 & $1.2 \times 10^{9}$ \\
\hline 7 & $100 \mathrm{~m}$ & 1 & Salmon & 0.01 & 0.02 & 0.03 & 0 & $\mathrm{i}$ & $1.7 \times 10^{\circ}$ \\
\hline 12 & Farm & 6 & Salmon & 0.00 & 0.01 & 0.00 & 0 & 2 & $1.1 \times 10^{8}$ \\
\hline 12 & $0 \mathrm{~m}$ & 7 & Coalfish & 0.03 & 0.02 & 0.00 & 0 & 1 & $2.8 \times 10^{9}$ \\
\hline
\end{tabular}

used was tryptone soya agar (TSA) in $70 \%$ seawater as recommended by Lunestad \& Goksøyr (1990) for determination of resistance of marine bacteria (tryptone soya broth $20 \mathrm{~g}$, Difco bacto agar $15 \mathrm{~g}, 70 \%$ seawater to $1 \mathrm{l}$ ). The plates were read after $3 \mathrm{~d}$ following aerobic incubation at $15^{\circ} \mathrm{C}$.

To determine the total number of bacteria and the number of Aeromonas salmonicida in the faeces of fish and blue mussel homogenate, each sample was homogenized for 1 min in a Waring blendor at low speed and diluted 1:1000 in prefiltered seawater. The samples were preserved with formaldehyde (final concentration $2 \%$ ) and the bacteria were stained using the techniques described by Hoff (1988) and Enger et al. (1989). These methods involve filtration of the sample through a $0.2 \mu \mathrm{m}$ Nucleopore filter and a staining of the bacteria with 4,6-diamidino-2-phenylindole (DAPI). When applying this method, DAPI diffuses from an underlying supporting filter previously soaked in DAPI solution $\left(100 \mu \mathrm{g} \mathrm{ml}^{-1}\right)$, staining the bacterial DNA. The bacteria present on the Nucleopore filter were also treated with monoclonal antibodies directed towards A. salmonicida. The antibodies used were diluted 1:800 in marine PBS $(20 \mathrm{~g} \mathrm{NaCl}$ and $4.3 \mathrm{~g}$ $\mathrm{MgCl}_{2} \cdot 6 \mathrm{H}_{2} \mathrm{O}$ in $1000 \mathrm{ml}$ distilled water adjusted to $\mathrm{pH}$ 7.2) containing $0.5 \%$ bovine serum albumin (Sigma Chemical Company, St. Louis, MO, USA). After 50 min the filters carrying the bacteria were washed $(3 \times)$ with aliquots of $3 \mathrm{ml}$ marine PBS. One $\mathrm{ml}$ of commercial FITC-conjugated rabbit anti-mouse immunoglobulin (DAkO, diluted 1:500 in marine PBS) was added and the filters kept at room temperature for $30 \mathrm{~min}$. The filters were washed twice with marine PBS before mounting on glass slides. The preparations were examined in a Zeiss standard fluorescence microscope with a HBO $50 \mathrm{~W}$ mercury lamp and a DAPI/FITC filter package as described by Enger et al. (1989). Immunofluorescent positive cells with a halo were only registered as positive counts of $A$. salmonicida if the bacteria also exhibited a positive DAPI signal.

\section{RESULTS}

A total of 46 wild fish and farmed salmon samples from Farm 1 were analysed for faecal antibacterial activity, total number of bacteria and the presence of Aeromonas salmonicida in faeces (Table 1). At Day 0, A. salmonicida was found in all of the 4 farmed salmon while none of the 8 coalfish tested were positive. Neither the farmed salmon nor the coalfish tested at Day 4 contained A. salmonicida in the gut. However, $7 \mathrm{~d}$ after termination of medication we found $A$. salmonicida in 2 out of 6 farmed salmon and in all 3 salmon caught at a distance of 0 to $100 \mathrm{~m}$ from the farm. On the 12 th day, A. salmonicida was found both in the farmed salmon and in 1 out of 7 coalfish.

High concentrations of OA in plasma, liver and muscle were found at both Days 0 and 4 in pelagic species (coalfish and mackerel) as well as in demersal species (haddock and crabs). Liver samples from wild fish generally had higher residual OA concentrations at Day 0 compared to muscle samples, but this difference had leveled out by Day 4. OA concentrations, particularly in coalfish, were considerably higher than in the farmed salmon tested at Days 0 and 4 (Tabies $2 \& 3$ ).

Fig. 3 shows the total catch of wild fish and crabs at Farms 1 and 2 and the number of $O A$-positive samples. 
Table 2. Residues of oxolinic acid $\left(\mu \mathrm{g} \mathrm{g}^{-1}\right)$ in wild fauna in the vicinity of Farm $1 . \mathrm{n}$ : total number of samples (in parentheses) and number of positive plasma, muscle, liver and homogenate samples. Mean: mean value of all positive samples; max: maximum concentration found. Coalfish $=$ Pollachius virens, ballan wrasse $=$ Labrus berggylta, ling $=$ Molva molva, crab $=$ Cancer pagurus, haddock = Melanogrammus aeglefinus, $\operatorname{cod}=$ Gadus morhua, pollack $=$ Pollachius pollachius, salmon = Salmo salar, blue mussel $=$ Mytllus edulis

\begin{tabular}{|c|c|c|c|c|c|c|c|c|c|c|c|c|}
\hline \multirow[t]{2}{*}{ Source of sample } & \multicolumn{3}{|c|}{ Day 0} & \multicolumn{3}{|c|}{ Day 4} & \multicolumn{3}{|c|}{ Day 7} & \multicolumn{3}{|c|}{ Day 13} \\
\hline & $\mathrm{n}$ & Mean & $\operatorname{Max}$ & $\mathrm{n}$ & Mean & $\operatorname{Max}$ & $\mathrm{n}$ & Mean & Max & $n$ & Mean & Max \\
\hline Coalfish & (33) & & & (13) & & & (14) & & & (18) & & \\
\hline Plasma & 33 & 1.56 & 7.12 & 13 & 0.99 & 3.11 & 10 & 0.16 & 0.65 & 2 & 0.03 & 0.04 \\
\hline Muscle & 33 & 5.19 & 10.71 & 13 & 3.92 & 12.51 & 14 & 0.22 & 0.81 & 14 & 0.02 & 0.03 \\
\hline Liver & 33 & 6.45 & 13.59 & 13 & 3.65 & 14.68 & 14 & 0.21 & 0.87 & 12 & 0.02 & 0.03 \\
\hline Ballan wrasse & $(2)$ & & & (10) & & & (6) & & & (3) & & \\
\hline Plasma & 2 & 0.01 & 0.19 & 6 & 0.04 & 0.15 & 3 & 0.04 & 0.07 & 0 & - & - \\
\hline Muscle & 2 & 0.49 & 0.92 & 10 & 0.44 & 1.37 & 5 & 0.03 & 0.08 & 0 & - & - \\
\hline Liver & 2 & 0.29 & 0.37 & 10 & 0.34 & 0.90 & 5 & 0.04 & 0.10 & 0 & - & - \\
\hline Ling & (3) & & & $\star$ & & & $\star$ & & & (1) & & \\
\hline Plasma & ns & - & - & - & - & - & - & - & - & - & - & - \\
\hline Muscle & 3 & 0.63 & 1.26 & - & - & - & - & - & - & 0 & - & - \\
\hline Liver & 3 & 0.89 & 1.49 & - & - & - & - & - & - & 0 & - & - \\
\hline Haddock & (2) & & & (1) & & & $\star$ & & & (1) & & \\
\hline Plasma & ns & - & - & 1 & 0.52 & - & - & - & - & 0 & - & - \\
\hline Muscle & 2 & 5.02 & 8.99 & 1 & 1.88 & - & - & - & - & 1 & 0.01 & 0.01 \\
\hline Liver & 2 & 5.21 & 9.21 & 1 & 0.72 & - & - & - & - & 1 & 0.01 & 0.01 \\
\hline Salmon & 太 & & & * & & & (3) & & & (2) & & \\
\hline Plasma & - & - & - & - & - & - & ns & - & - & ns & - & - \\
\hline Muscle & - & - & - & - & - & - & 2 & 0.12 & 0.23 & 1 & 0.1 & 0.1 \\
\hline Liver & - & - & - & - & - & - & 2 & 0.30 & 0.47 & 1 & 0.06 & 0.06 \\
\hline Cod and pollack & (2) & & & $(8)$ & & & (4) & & & $(8)$ & & \\
\hline Plasma & 2 & 0.05 & 0.09 & 7 & 0.03 & 0.05 & 4 & 0.03 & 0.06 & 0 & - & - \\
\hline Muscle & 2 & 0.42 & 0.62 & 7 & 0.10 & 0.37 & 4 & 0.02 & 0.03 & 3 & 0.02 & 0.02 \\
\hline Liver & 2 & 0.23 & 0.35 & 7 & 0.11 & 0.30 & 4 & 0.08 & 0.25 & 3 & 0.01 & 0.01 \\
\hline Blue mussels & (5) & & & (5) & & & (3) & & & - & & \\
\hline Homogenate & 5 & 0.65 & 1.48 & 3 & 0.05 & 0.09 & 0 & - & - & - & - & - \\
\hline Crab & (5) & & & (13) & & & $(10)$ & & & (12) & & \\
\hline Haemolymph & 3 & 0.13 & 0.22 & 12 & 0.19 & 1.23 & 6 & 0.19 & 0.77 & 2 & 0.03 & 0.04 \\
\hline Muscle & 5 & 0.81 & 3.77 & 11 & 0.45 & 1.61 & 6 & 0.08 & 0.25 & 4 & 0.03 & 0.09 \\
\hline
\end{tabular}

In this investigation a positive sample was defined as one having a residual $O A$ concentration exceeding $10 \mathrm{ng} \mathrm{g}^{-1}$ tissue or $10 \mathrm{ng} \mathrm{ml}^{-1}$ plasma. Considering the large number of plasma samples on Day 7 at Farm 2 having no residual $O A$, we found it unnecessary to analyse the muscle and liver samples.

One sample ( $1 \mathrm{~g}$ ) of homogenised tissue from 15 blue mussels collected on Farm 2 (Day 0) contained $0.07 \mu \mathrm{g}$ $\mathrm{g}^{-1}$ of OA and had levels of OA-resistant bacteria more than 10 times higher than those found in similar samples from blue mussels collected 200 and $400 \mathrm{~m}$ away. The blue mussels collected at 200 and $400 \mathrm{~m}$ had no detectable OA residues. At Day 7, blue mussels collected at Farm 2 contained no OA and had levels of OAresistant bacteria similar to the mussels from 200 and $400 \mathrm{~m}$ (Day 0).

\section{DISCUSSION}

Oxolinic acid (OA) was first described in 1968 (Kaminsky \& Meltzer 1968). OA inhibits microbial growth by interfering with DNA gyrase activity and is effective on Gram-negative bacteria (Wolfson et al. 1989). Gram-positive bacteria and anaerobes are usually not susceptible to OA (Walter \& Heilmeyer 1975. Wolfson et al. 1989). Single step mutations leading to high-level resistance towards OA in bacteria have been reported to occur with frequencies in the range $10^{-6}$ to $10^{-8}$. This creates the possibility of emergence of resistant organisms during therapy (Wolfson et al. 1989). On the other hand there have been no descriptions of transferable or plasmidmediated resistance towards OA (Wolfson et al. 1989). 
Table 3. Residues of oxolinic acid $\left(\mu \mathrm{g} \mathrm{g}^{-1}\right)$ in wild fauna in the vicinity of Farm 2. $\mathrm{n}$ : total number of samples (in parentheses) and number of positive plasma, muscle and liver samples. Mean: mean value of all positive samples; max: maximum concentration found . Coalfish $=$ Pollachius virens, crab = Cancer pagurus, $\operatorname{cod}=$ Gadus morhua, haddock = Melanogrammus aeglefinus, pollack = Pollachius pollachius, salmon = Salmo salar, flounder = Platichthys flesus, mackerel = Scomber scombrus

\begin{tabular}{|c|c|c|c|c|c|c|c|c|c|}
\hline \multirow[t]{2}{*}{ Source of sample } & \multirow[b]{2}{*}{$\mathrm{n}$} & \multicolumn{2}{|l|}{ Day 0} & \multicolumn{3}{|c|}{ Day 7} & \multicolumn{3}{|c|}{ Day 13} \\
\hline & & Mean & $\operatorname{Max}$ & $\mathrm{n}$ & Mean & $\operatorname{Max}$ & $n$ & Mean & $\operatorname{Max}$ \\
\hline Coalfish & (4) & & & (5) & & & & & \\
\hline Plasma & 4 & 0.96 & 2.41 & 1 & 0.02 & 0.02 & - & - & - \\
\hline Muscle & 4 & 1.04 & 2.42 & 1 & 0.02 & 0.02 & - & - & - \\
\hline Liver & 4 & 1.86 & 5.60 & 1 & 0.01 & 0.01 & - & - & - \\
\hline Mackerel & (6) & & & (2) & & & & & \\
\hline Plasma & 5 & 0.16 & 0.73 & 0 & - & - & - & - & - \\
\hline Muscle & 5 & 0.37 & 2.23 & na & - & - & - & - & - \\
\hline Liver & 5 & 0.43 & 2.04 & na & - & - & - & - & - \\
\hline Cod & (2) & & & $(2)$ & & & & & \\
\hline Plasma & 0 & - & - & 0 & - & - & - & - & - \\
\hline Muscle & 2 & 0.03 & 0.05 & na & - & - & - & - & - \\
\hline Liver & 2 & 0.02 & 0.03 & na & - & - & - & - & - \\
\hline Pollack & (2) & & & (16) & & & & & \\
\hline Plasma & 2 & 0.03 & 0.03 & 0 & - & - & - & - & - \\
\hline Muscle & 2 & 0.03 & 0.03 & na & - & - & - & - & - \\
\hline Liver & 2 & 0.03 & 0.04 & na & - & - & - & - & - \\
\hline Salmon & $(2)$ & & & * & & & & & \\
\hline Plasma & 0 & - & - & - & - & - & - & - & - \\
\hline Muscle & 0 & - & - & - & - & - & - & - & - \\
\hline Liver & 0 & - & - & - & - & - & - & - & - \\
\hline Flounder & (3) & & & (4) & & & & & \\
\hline Plasma & 1 & 0.10 & 0.10 & 0 & - & - & - & - & - \\
\hline Muscle & 1 & 0.03 & 0.03 & na & - & - & - & - & - \\
\hline Liver & 1 & 0.01 & 0.01 & na & - & - & - & - & - \\
\hline Crab & (4) & & & $(22)$ & & & (11) & & \\
\hline Haemolymph & 2 & 0.02 & 0.02 & 8 & 0.09 & 0.56 & 0 & - & - \\
\hline Muscle & 2 & 0.01 & 0.02 & 8 & 0.13 & 0.87 & 1 & 0.02 & 0.02 \\
\hline
\end{tabular}

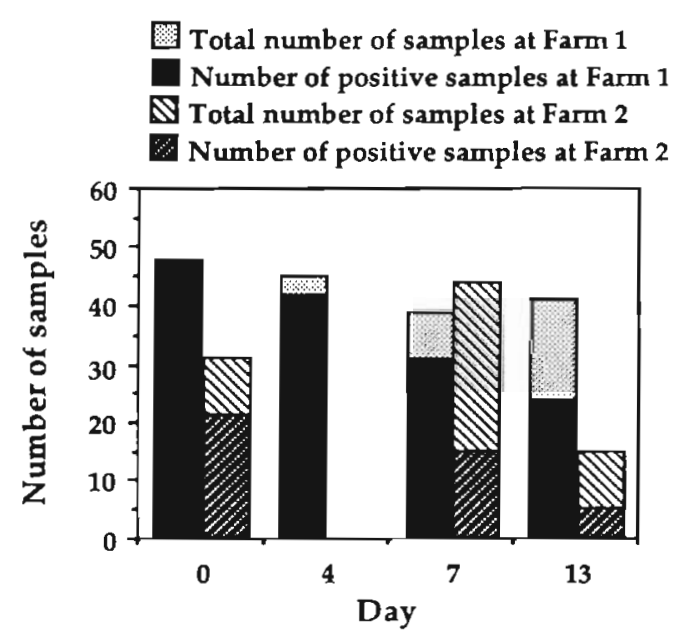

Fig. 3. Total number of samples and number of positive muscle samples at Farms 1 and 2. Number of positive samples at Farm 2, Day 7, are based on results from the plasma analysis
High doses of OA in fish have been reported to cause haematological disturbances and adverse effects on liver (Miyazaki et al. 1984).

In higher animals, OA is associated with toxic effects on the central nervous system (CNS) and with gastrointestinal irritation (Goldberg et al. 1961, Walter \& Heilmeyer 1975, Mandel \& Sande 1985, Crumplin 1988). Furthermore, OA is suspected to interfere with gene transcription in mammalian cells (Crumplin 1988). Due to the relatively high incidence of adverse effects and the narrow spectrum of activity, $O A$ has never been considered a first line antimicrobial agent in clinical practice. However, the newer quinolones are promising. The incidence of adverse effects with the third generation quinolones seems to be reduced and the spectrum of activity has been broadened, making the new compounds more attractive for the treatment of bacterial diseases in humans (Moellering 1989).

In this investigation we examined a total of 225 fish, 76 crabs and 30 samples of blue mussels. Residues of 
OA were detected in coalfish, mackerel, cod, haddock, whiting, ling, pollack, ballan wrasse, wild salmon, crabs and blue mussels. On the day medication was terminated the average concentration of $O A$ in positive

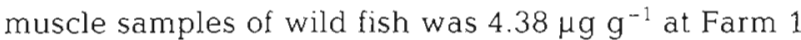
and $0.42 \mu \mathrm{g} \mathrm{g}^{-1}$ at Farm 2. The highest concentration of OA in muscle $\left(12.51 \mu \mathrm{g} \mathrm{g}^{-1}\right)$ was found in a coalfish caught at Farm 1 on Day 0. Even in fish caught $400 \mathrm{~m}$ away from Farm 1 at a depth of nearly $100 \mathrm{~m}$, residues were found. These findings exceed by far the drug concentrations allowable in food for human consumption in many countries, including Norway. These countries have general regulations requiring the complete absence of drug residues in food. Thus, in practice, the detection limit of the method employed is then the maximum level permitted. At present the detection limit of the microbiological test in use in Norway is $0.10 \mu \mathrm{g} \mathrm{g}^{-1}[\mathrm{H}$. Evensen (Directorate of Fisheries, Control laboratory) pers. comm.]. The detection limits of the different HPLC methods available are 0.0005 to $0.010 \mu^{-1} \mathrm{~g}^{-1}$ (Bjørklund 1989, Rogstad et al. 1989, Andresen \& Rasmussen 1990, Steffenak et al. 1991). Twelve days after termination of medication, only minor concentrations of OA could be found in the tissues of the species examined. The farmed salmon contained much lower concentrations of OA than most of the wild living fishes. This reflects the usually low appetite of diseased fish.

A considerable number of the fish examined had high concentrations of $O A$ in the gut at Day 0 and 4 . It is not yet known whether the high antibacterial activity is due to residues of drug from food intake or to excreted $\mathrm{OA}$ and microbiologically cleaved $\mathrm{OA}$ conjugates from the bile. However, HPLC analysis of samples collected from salmon treated with OA showed residues of both unchanged and conjugated OA in the bile (Samuelsen unpubl.). It is possible for drug conjugates in the bile to be transformed to active drug by the intestinal bacteria and then reabsorbed (enterohepatic circulation). Four other fish farms were situated in the same area as Farm 1. In these farms, a total of 660 tonnes of salmon were treated with OA during the same period as treatment at Farm 1. This may partly account for the high residues of $O A$ in the fish and large number of positive samples at Farm 1.

When OA was detected in the intestinal contents, the inhibition zones produced varied between 12 and $30 \mathrm{~mm}$ in diameter. Fish containing OA in faeces usually had high concentrations of the drug in liver, muscle and plasma. Considering the positive correlation with the HPLC method, the microbiological assay could be valuable in the investigation of drug residues in both farmed and wild organisms since the microbiological method is rapid and does not require expensive equipment.
Several authors reported an increase in the number of resistant faecal bacteria during antibacterial treatment in humans (Goldberg et al. 1961, Datta et al. 1971). This has also been reported to occur in the treatment of fish (Aoki et al. 1972, Toranzo et al. 1984, Schlotfeldt et al. 1985). In previous years an increase in the occurrence of the pathogenic fish bacteria Aeromonas salmonicida and Yersinia ruckeri (causal agent of enteric redmouth disease) resistant to OA has been reported (Hastings \& McKay 1987, O'Grady et al. 1987, Tsoumas et al. 1989). It is therefore reasonable to believe that this decrease in susceptibility is caused by the widespread use of OA in the treatment. On the other hand Sugita et al. (1989) reported that OA did not markedly influence the number of bacteria, the bacterial ability to resist OA and the intestinal bacterial flora of goldfish Carassius auratus during a standard treatment.

Aeromonas salmonicida and OA were present simultaneously in the gut of wild and farmed salmon (Table 1). This may permit A. salmonicida to develop resistance towards $O A$ and, via faeces, be spread to the environment. In this manner furunculosis can be spread to the wild fish population and further to other fish farms by OA resistant bacteria.

Marine bivalves have frequently been employed in the assessment of environmental pollution. Their wide distribution and low level of xenobiotic metabolism combined with a sessile adult behavior and high filter activity makes these organisms especially suitable for the detection of pollutants (Krieger et al. 1981). In our investigation we found low to moderate concentrations of $\mathrm{OA}$ in the blue mussels examined. Despite low concentrations of $\mathrm{OA}$ in blue mussels at Farm 2, an increased percentage of OA-resistant bacteria could be observed in samples taken immediately after termination of medication. One explanation may be that the mussels have filtered out resistant bacteria shed from the intestine of fish receiving the drug. At low pumping rates blue mussels have been reported to be capable of retaining particles as small as $2 \mu \mathrm{m}$. At high pumping rates all particles larger than $6 \mu \mathrm{m}$ are retained (Dral 1967, Vahl 1972). However, most marine bacteria are too small to be retained efficiently by blue mussels if not aggregated or present on debris (Wright et al. 1982). Some of the bacteria in the intestine of fish may well be associated with faecal particles which are filterable by blue mussels. Bacteria found on soft tissue surfaces of blue mussels at Day 7 after termination of medication had no elevated level of bacteria resistant to $O A$. There is reason to believe that the bacterial flora of blue mussels reflects the flora present in the water. When the concentration of OA in the farmed and wild fish intestine decreases, the number of resistant bacteria released into the seawater will also decrease. 
Since it is a well established principle that residues of medicines given to livestock animals should not be found in food for human consumption, considerable efforts are made to prevent drug transfer in this way. However, the present investigation clearly shows that during medication the wild fauna near a fish farm is exposed to the drug in use. If wild fish, crustaceans or mussels are harvested in the vicinity of an aquaculture facility during medication, the risk of drugs reaching consumers is high. In the case of OA, the drug is also rather thermostable and no reduction in antibacterial activity could be observed when an aqueous solution of the drug was boiled for $15 \mathrm{~min}$ to simulate conditions resembling normal treatment of fish.

Combined with a compulsory announcement of medication, collection of medicated food particles that fall through the net pens and optimisation of the medication strategy will reduce the problem. Since there is no obvious reason to distinguish between free-living and farmed animals in regard to drug residues, monitoring of exploitable wild animals exposed to drugs from aquaculture, similar to that with farmed fish, should be considered.

Acknowledgements. The technical assistance of Ms Eli Tepstad, Mr Audun Høylandskjær and Mr Finn Chr. Foldrup is highly appreciated. We thank Kåre $\mathrm{O}$. Holm at Apotekernes Laboratorium (Tromse), for the supply of monoclonal antibodies against Aeromonas salmonicida and the owners and workers at the salmon farms for valuable information and help during sampling. We also thank Ms Beth $\mathrm{C}$. Hølleland and Prof. R. R. Scheline for critical comments on the manuscript. This investigation was supported financially by The Norwegian Research Council for Fisheries Science and The Fishermens Association, Division Hordaland.

\section{LITERATURE CITED}

Andresen, A. T., Rasmussen, K. E. (1990). Automated on-line dialysis and column-switching HPLC determination of flumequine and oxolinic acid in fish liver. J. liq. Chromatogr. 13: 4051-4065

Aoki, T., Egusa, S., Yada, C., Watanabe, T (1972). Studies of drug resistance and $R$ factors in bacteria from pondcultured salmonids. Jap. J. Microbiol. 16: 233-238

Bjørklund, H. V. (1989). Analysis of oxolinic acid in fish by high-performance liquid chromatography. J. Chromatogr. 530: $75-82$

Björklund, H., Bondestam, J., Bylund, G. (1990). Residues of oxytetracycline in wild fish and sediments from fish farms. Aquaculture 86: 359-367

Carss, D. N. (1990). Concentrations of wild and escaped fishes immediately adjacent to fish farm cages. Aquaculture 90 $29-40$

Crew, M. C., Melgar, M. D., Haynes, L. J., Gala, R. L., DiCarlo, F. J. (1971). Comparative metabolism of oxolinic acid by the rat, rabbit and dog. Xenobiotica 1. 193-201

Crumplin, G. C. (1988). Aspects of chemistry in the development of the 4-quinolone antibacterial agents. Rev. infect Dis. 10: $2-9$
Datta, N., Faters, M. C., Reeves, D. S., Brumfitt, W., Ørskov, F. Ørskov, I. (1971). R-factors in Escherichia coli in faeces after oral chemotherapy in general practice. Lancet, Feb 13: $312-313$

DiCarlo, F. J., Crew, M. C., Melgar, M. D., Roemer, S., Ringel, S. M., Haynes, L. J., Wilson, M. (1968). Oxolinic acid metabolism by man. Arch, int. Pharmacodyn. 174 $413-427$

Dral, A. D. G. (1967). The movements of the latero-frontal cilia and the mechanism of particle retention in the mussel. (Mytilus edulis L.). Neth. J. Sea Res. 3: 391-422

Enger, Ø., Husevåg, B, Goksøyr, J. (1989). Presence of the fish pathogen Vibrio salmonicida in fish farm sediments. Appl. environ. Microbiol. 55: 2815-2818

Goldberg, H. S., Goodman, R. N., Logue, J. T., Handler, F. P. (1961). Longterm, low-level antibiotics and the emergence of antibiotic-resistant bacteria in human volunteers. Antimicrob. Agents Chemother. 1: 80-88

Hastings, T. S., McKay, A. (1987). Resistance of Aeromonas salmonicida to oxoline acid. Aquaculture 61: 165-171

Higuera, I. C., Brown, J. H., Jauncey, K. (1990). Leaching of oxytetracycline from pelleted shrimp feeds. Abstract from a lecture held at the conference, 26-29 June, 'Bacterial diseases of fish' at the University of Sterling, Scotland

Hoff, K. A. (1988). Rapid and simple method for double staining of bacteria with 4,6-diamidino-2-phenylindole and fluorescein isothiocyanate labelling antibodies. Appl. environ. Microbiol. 54: 2949-2952

Jacobsen, P., Berglind, L. (1988\}. Persistence of oxytetracycline in sediments from fish farms. Aquaculture 70: $365-370$

Kaminsky, D., Meltzer, R. J. (1968). Quinolone antibacterial agents. Oxolinic acid and related compounds. J. med. Chem. 11: 160-162

Krieger, R. I., Gee, S. J., Lim, L.O. (1981). Marine bivalves, particularly mussels, Mytilus sp., for assessment of environmental quality. Ecotoxicol. Environ. Safety 5: 72-86

Lunestad, B. T., Goksøyr, J (1990). Reduction in the antibacterial effect of oxytetracycline in sea water by complex formation with magnesium and calcium. Dis. aquat. Org. 9: $67-72$

Mandell, G. L., Sande, M. A. (1985), Sulfonamides, irimethoprim-sulfamethoxazole, and agents for urinary tract infections. In: Goodman \& Gilman's. The pharmacological basis of therapeutics, 7th edn. MacMillan, New York, p. $1109-1111$

Miyazaki, T., Nakauchi, R., Kubota, S. S. (1984). Toxicological examinations of oxolinic acid and nalidixic acid in yellow. tail. Bull. Fac. Fish. Mie Univ. 11:15-26

Moellering, R. C. (1989). Quinolone antibacterial agents: overview and conclusions. In: Wolfson, J. S., Hooper, D. C. (eds.) Quinolone antibacterial agents. American Society for Microbiology, Washington, D.C., p. 273-283

Møster, G. (1986). Bruk av antibiotika i fiskeoppdrett. (The use of antibiotics in Norwegian fish farming). Sogn og Fjordane Distriktshøgskole, 5800 Sogndal, Norway, 58 p. (in Norwegian)

Nusbaum, K. E., Shotts, E. B. Jr (1981). Absorption of selected antimicrobic drugs from water by channel catfish, Ictalurus punctatus. Can. J. Fish Aquat. Sci. 38: 993-996

O'Grady, P., Palmer, R., Rodger, H., Smith, P. (1987). Isolation of Aeromonas salmonicida strains resistant to the quinoline antibiotics. Bull. Eur. Ass. Fish Pathol. 7: 43

Rogstad, A., Hormazabal, V., Yndestad, M. (1989). Simultaneous extraction and determination of oxolinic acid and flumequine in fish tissues by high-performance liquid chromatography. J. liq. Chromatogr. 12: 3073-3086 
Samuelsen, O.B. (1989). Determination of flumequine in fish by high-performance liquid chromatography and fluorescence detection. J. Chromatogr. 497: 355-359

Samuelsen, O. B. (1990). Simple and rapid method for the determination of flumequine and oxolinic acid salmon (Salmo salar) plasma by high-performance liquid chromatography and fluorescence detection. J. Chromatogr. 530: $452-457$

Samuelsen, O. B., Torsvik, V. L., Ervik, A. (in press). Longrange changes in oxytetracycline concentration and bacterial resistence towards oxytetracycline in a fish farm sediment after medication. Sci, tot. Environ.

Schlotfeldt, H. J., Neumann, W., Fuhrman, H., Pfortmueller, K., Boehm, H. (1985). Remarks on increasing resistance of fish pathogenic and facultative fish pathogenic bacteria in Lower Saxony (FRG). Fish Pathol. 20: 85-91

Steffenak, I., Hormazabal, V., Yndestad, M. (1991). Rapid assay for the simultaneous determination of residues of oxolinic acid and flumequine in fish tissues by highperformance liquid chromatography. J. liq. Chromatogr. 14: $61-70$

Sugita, H., Miyajima, C., Fukumoto, M., Koyama, H., Degu-

Responsible Subject Editor: O. Kinne, Oldendorf/Luhe, Germany chi, Y. (1989). Effect of oxoline acid on fecal microflora of goldfish (Carassius auratus). Aquaculture 80: 163-174

Toranzo, A. E., Combarro, P., Lemos, M. L., Barja, J. L. (1984) Plasmid coding for transferable drug resistance in bacteria isolated from cultured rainbow trout. Appl, environ. Microbiol $48: 872-877$

Tsoumas, A., Rodgers, C. J. (1989). Aeromonas salmonicida development of resistance to 4 -quinolone antimicrobials. J. Fish Dis. 12: 493-507

Vahl, O. (1972). Efficiency of particle retention in Mytilus edulis L. Ophelia 10: 17-25

Walter, A. M., Heilmeyer, L. (1975). Antibiotika-Fibel. Georg Thieme Verlag, Stuttgart

Wolfson, J. S., Hooper, D. C., Swartz, M. N. (1989). Mechanisms of action and of resistance to quinolone antibacterial agents. In: Wolfson, J. S., Hooper, D. C. (eds.) Quinolone antibacterial agents. American Society for Microbiology, Washington, D.C., p. 5-34

Wright, R. T., Coffin, R. B., Ersing, C. P., Pearson, D. (1982) Field and laboratory measurements of bivalve filtration of natural marine bacterioplankton. Limnol. Oceanogr. 27: $91-98$

Manuscript first received: July 9, 1991

Revised version accepted: October 7, 1991 